\title{
Estradiol Induces Diurnal Shifts in GABA Transmission to Gonadotropin-Releasing Hormone Neurons to Provide a Neural Signal for Ovulation
}

\author{
Catherine A. Christian and Suzanne M. Moenter \\ Neuroscience Graduate Program, Departments of Medicine and Cell Biology, University of Virginia, Charlottesville, Virginia 22908
}

\begin{abstract}
Ovulation is initiated by a surge of gonadotropin-releasing hormone $(\mathrm{GnRH})$ secretion by the brain. GnRH is normally under negative feedback control by ovarian steroids. During sustained exposure to estradiol in the late follicular phase of the reproductive cycle, however, the feedback action of this steroid switches to positive, inducing the surge. Here, we used an established ovariectomized, estradiol-treated $(\mathrm{OVX}+\mathrm{E})$ mouse model exhibiting daily surges to investigate the neurobiological mechanisms underlying this switch. Specifically, we examined changes in GABA transmission to GnRH neurons, which can be excited by $\mathrm{GABA}_{\mathrm{A}}$ receptor activation. Spontaneous GABAergic postsynaptic currents (PSCs) were recorded in GnRH neurons from OVX $+\mathrm{E}$ and OVX mice in coronal and sagittal slices. There were no diurnal changes in PSC frequency in cells from OVX mice in either slice orientation. In OVX $+\mathrm{E}$ cells in both orientations, PSC frequency was low during negative feedback but increased at surge onset. During the surge peak, this increase subsided in coronal slices but persisted in sagittal slices. Comparison of PSCs before and during tetrodotoxin (TTX) treatment showed TTX decreased PSC frequency in OVX $+\mathrm{E}$ cells in sagittal slices, but not coronal slices. This indicates estradiol acts on multiple GABAergic afferent populations to increase transmission through both activity-dependent and -independent mechanisms. Estradiol also increased PSC amplitude during the surge. Estradiol and the diurnal cycle thus interact to induce shifts in both GABA transmission and postsynaptic response that would produce appropriate changes in GnRH neuron firing activity and hormone release.
\end{abstract}

Key words: GnRH; LH; GABA; postsynaptic current; estradiol; ovulation

\section{Introduction}

Gonadotropin-releasing hormone (GnRH) neurons form the final common pathway by which the CNS regulates fertility. In females, ovarian steroid hormones exert both negative and positive feedback to modulate GnRH neuron function and pituitary responsiveness to $\mathrm{GnRH}$. At the end of the follicular phase (proestrus in rodents), estradiol feedback switches from negative to positive action, causing a large surge in GnRH release (Sarkar et al., 1976; Moenter et al., 1991; Pau et al., 1993), likely driven by increased GnRH neuron firing activity (Christian et al., 2005). The GnRH surge initiates the pituitary luteinizing hormone (LH) surge that subsequently triggers ovulation. In rodents, estradiol interacts with a circadian signal so that the surge is timed to a specific time of day, specifically late afternoon in nocturnal species (Norman et al., 1973; Legan and Karsch, 1975; Christian et al., 2005). In many women, the diurnal tendency persists as the

Received Oct. 31, 2006; revised Dec. 21, 2006; accepted Jan. 18, 2007.

This work was supported by National Institute of Child Health and Human Development-National Institutes of Health Grant R01 HD41469 and National Institute of Neurological Disorders and Stroke National Research Service Award F31 NS53253 (C.A.C.). We thank Debra Fisher and Xu-Zhi Xu for expert technical assistance and Zhiguo Chu, Tony DeFazio, Justyna Pielecka-Fortuna, Alison Roland, Pei-San Tsai, and Heidi Walsh for helpful editorial comments.

Correspondence should be addressed to Suzanne M. Moenter, P.0. Box 800578, University of Virginia, Charlottesville, VA 22908. E-mail: moenter@virginia.edu.

DOI:10.1523/JNEUROSCI.4738-06.2007

Copyright $\odot 2007$ Society for Neuroscience $\quad$ 0270-6474/07/271913-09\$15.00/0
LH surge tends to occur in the early morning (Kerdelhue et al., 2002).

Estradiol signals to GnRH neurons are likely mediated via estrogen-sensitive afferents because GnRH neurons do not appear to express the $\alpha$ isoform of the estrogen receptor $(\operatorname{ER} \alpha)$, which is crucial for feedback control (Herbison, 1998; Wintermantel et al., 2006). ER $\alpha$ knock-out mice do not show normal homeostatic regulation of the $\mathrm{GnRH} / \mathrm{LH}$ axis or $\mathrm{LH}$ surges (Couse and Korach, 1999) and are infertile. One candidate neurotransmitter that may convey estradiol signals to $\mathrm{GnRH}$ neurons is GABA, which provides a major synaptic input to $\mathrm{GnRH}$ neurons (Leranth et al., 1985b; Jansen et al., 2003; Pompolo et al., 2003). Hypothalamic GABAergic cells express ER $\alpha$ (Flugge et al., 1986; Leranth et al., 1991) and GnRH neurons express $\mathrm{GABA}_{\mathrm{A}}$ receptors $\left(\mathrm{GABA}_{\mathrm{A}} \mathrm{Rs}\right)$ that are synaptically activated (Sim et al., 2000; Sullivan et al., 2003). GABA $\mathrm{R}$ activation can inhibit or excite a cell depending on intracellular chloride levels (Kaila, 1994; Rivera et al., 1999) and membrane voltage. Although still controversial (Han et al., 2002, 2004), there is considerable evidence that GnRH neurons fall into the growing group of adult central neurons that maintain elevated intracellular chloride resulting in depolarization and potentially excitation on $\mathrm{GABA}_{\mathrm{A}} \mathrm{R}$ activation (DeFazio et al., 2002; Marty and Llano, 2005; Moenter and DeFazio, 2005; Yin et al., 2006). Furthermore, the frequency of GABA transmission to GnRH neurons and GnRH neuron responsiveness to GABA are positively correlated with reproduc- 
tive state (Bilger et al., 2001; Sullivan et al., 2003; Sullivan and Moenter, 2004a,b, 2005).

Here, we investigate the relationship of estradiol, the diurnal cycle, and GABA transmission directly at the level of the GnRH neuron. We used a mouse model that exhibits daily GnRH/LH surges during constant in vivo physiological estradiol treatment (Christian et al., 2005) to test the hypothesis that GABA transmission to GnRH neurons increases in association with the GnRH surge. Our findings indicate estradiol induces shifts in GABA transmission at appropriate times of day to generate and correctly time a neural signal for ovulation.

\section{Materials and Methods}

Animals. Adult (2-4 months of age) transgenic female mice in which green fluorescent protein (GFP) is genetically targeted to $\mathrm{GnRH}$ neurons (Suter et al., 2000) were used. Mice were on a $14 / 10 \mathrm{~h}$ light/dark photoperiod with lights off at 4:30 P.M. eastern standard time, with Harlan (Indianapolis, IN) 2916 chow and water available ad libitum. To rapidly establish constant physiological estradiol levels and induce daily LH surges, mice were ovariectomized under isoflurane (Burns Veterinary Supply, Westbury, NY) anesthesia and either simultaneously implanted with a SILASTIC capsule (Dow-Corning, Midland, MI) containing 0.625 $\mu \mathrm{g}$ of estradiol suspended in sesame oil $(\mathrm{OVX}+\mathrm{E})(n=94$ mice $)$ or not treated further (OVX) ( $n=42)$ as described previously (Christian et al., 2005). Postoperative analgesia was provided by the long-acting local anesthetic bupivicaine $(0.25 \% ; 7 \mu \mathrm{l}$ per site; Abbott Laboratories, North Chicago, IL). Estradiol was administered in vivo and was not present in any recording solutions. All procedures were approved by the University of Virginia Animal Care and Use Committee.

Slice preparation. Reagents were purchased from Sigma (St. Louis, MO) unless noted. Two to $4 \mathrm{~d}$ after OVX surgery, brain slices were prepared with slight modifications (Christian et al., 2005; Chu and Moenter, 2005) of previous descriptions (Nunemaker et al., 2002, 2003). Briefly, mice were killed at three different times that correspond to negative feedback (0900-1030 h), surge onset (1230-1300 h), and surge peak $(1430-1500 \mathrm{~h})$ in estradiol-treated animals (see Fig. 1). The brain was rapidly removed and placed in ice-cold high-sucrose saline solution containing the following (in mM): 250 sucrose, $3.5 \mathrm{KCl}, 26 \mathrm{NaHCO}_{3}, 10$ D-glucose, $1.3 \mathrm{NaHPO}_{4}, 1.2 \mathrm{MgSO}_{4}, 3.8 \mathrm{MgCl}_{2}$. Coronal $(200$ or $300 \mu \mathrm{m})$ or sagittal $(300 \mu \mathrm{m})$ slices were cut with a Vibratome 3000 (Ted Pella, Redding, CA); slice thickness did not affect results. Slices were incubated for $30 \mathrm{~min}$ at $30-32^{\circ} \mathrm{C}$ in $50 \%$ high-sucrose saline and $50 \%$ normal saline (NS) solution, containing the following (in $\mathrm{mm}$ ): $135 \mathrm{NaCl}, 3.5$ $\mathrm{KCl}, 26 \mathrm{NaHCO}_{3}, 10$ D-glucose, $1.25 \mathrm{NaH}_{2} \mathrm{PO}_{4}, 1.2 \mathrm{MgSO}_{4}, 2.5 \mathrm{CaCl}_{2}$, $\mathrm{pH}$ 7.4. Slices were then transferred to $100 \% \mathrm{NS}$ solution at room temperature $\left(\sim 21-23^{\circ} \mathrm{C}\right)$ for $0.5-2.5 \mathrm{~h}$. For recording, slices were placed in a recording chamber on the stage of an Olympus BX50WI upright fluorescent microscope (Opelco, Dulles, VA) and continuously superfused at $5-6 \mathrm{ml} / \mathrm{min}$ with oxygenated NS at $30-32^{\circ} \mathrm{C}$. Slices were stabilized in the chamber for $\geq 5$ min before recording.

Recordings. GFP-GnRH neurons in the preoptic area and ventral hypothalamus were identified by brief illumination at $470 \mathrm{~nm}$. Experiments were performed using an EPC 8 amplifier (HEKA Elektronik, Lambrecht/Pfalz, Germany) with the Pulse Control XOP (Instrutech, Port Washington, NY) running in Igor Pro software (Wavemetrics, Lake Oswego, OR) on a G4 Macintosh computer. Signals were digitized at 16-bit resolution through an ITC-18 acquisition interface (Instrutech). Recordings were performed at three different times: between 1100 and $1400 \mathrm{~h}$ (negative feedback), 1400 and $1600 \mathrm{~h}$ (surge onset), and 1600 and $1900 \mathrm{~h}$ (surge peak) (see Fig. 1). An average of two, but no more than four, cells per animal and only one cell per slice were recorded. The location of each GnRH neuron studied was mapped on figures of sections obtained from a mouse brain atlas (Paxinos and Franklin, 2001).

Recording pipettes (2-3 M $\Omega$ ) were filled with isotonic chloride pipette solution (140 mM KCl, $10 \mathrm{~mm}$ HEPES, $5 \mathrm{~mm}$ EGTA, and $0.1 \mathrm{~mm} \mathrm{CaCl}_{2}$ ) with the addition of $4 \mathrm{~mm} \mathrm{MgATP}$ and $0.4 \mathrm{~mm} \mathrm{NaATP}$ before adjusting to $\mathrm{pH} 7.3$ with $\mathrm{NaOH}$. To isolate GABAergic currents, APV [D-(-)-2amino-5-phosphonovaleric acid] $(20 \mu \mathrm{M})$ and CNQX (6-cyano-7- nitroquinoxaline) $(10 \mu \mathrm{M})$ were included in the recording saline to block glutamatergic currents. In some recordings, tetrodotoxin (TTX) $(0.5 \mu \mathrm{M}$; Calbiochem, La Jolla, CA) was added to block action potentials. In a subset of experiments, the $\mathrm{GABA}_{\mathrm{A}}$ receptor antagonist bicuculline (20 $\mu \mathrm{M})$ was applied to confirm these currents were mediated by the $\mathrm{GABA}_{\mathrm{A}} \mathrm{R}$. Membrane potential was clamped at $-60 \mathrm{mV}$, and signals were low-pass filtered at $7 \mathrm{kHz}$ with gain set at $10 \mathrm{mV} / \mathrm{pA}$. Under these conditions, $\mathrm{GABA}_{\mathrm{A}} \mathrm{R}$-mediated postsynaptic currents (PSCs) recorded appear as inward currents. Liquid junction potential of $3 \mathrm{mV}$ (Barry, 1994) was not corrected for. The $120 \mathrm{~s}$ recordings were stored as Event Tracker files using Pulse Control and Igor Pro software. Input resistance $\left(R_{\mathrm{in}}\right)$, series resistance $\left(R_{\mathrm{s}}\right)$, and membrane capacitance $\left(C_{\mathrm{m}}\right)$ were continually monitored as described previously (DeFazio et al., 2002; DeFazio and Moenter, 2002). Only recordings with $R_{\text {in }}>500 \mathrm{M} \Omega, R_{\mathrm{s}}<20 \mathrm{M} \Omega$, and $C_{\mathrm{m}}>10 \mathrm{pF}$, and holding current between 0 and $-60 \mathrm{pA}$ were included for analysis. There were no differences among groups in any passive recording properties or series resistance attributable to steroid treatment or time of day.

Analysis. Stored $120 \mathrm{~s}$ traces of PSC activity were analyzed off-line using custom event detection software in Igor Pro (Sullivan et al., 2003). Events were confirmed by eye, and detection errors were corrected manually. The mean event frequency (in hertz) was calculated from two to five $120 \mathrm{~s}$ records for each cell to obtain the mean PSC frequency for each group. For examination of TTX effects, three $120 \mathrm{~s}$ records were used as control, and the last two of three $120 \mathrm{~s}$ records obtained in the presence of TTX were used in analysis to allow for exchange of bath solutions. Peak amplitude and interevent interval were calculated by the program for each event. Averaged PSC waveforms were generated for each cell after aligning events on the rising phase and were used to illustrate differences in PSC amplitude.

Data were transferred to Excel (Microsoft, Redmond, WA) or InStat (Graph Pad Software, San Diego, CA) for statistical analysis. Group means for the three recording times were compared within OVX and OVX + E treatments using one-way ANOVA followed by post hoc analysis with Student-Newman-Keuls tests, or Kruskal-Wallis tests followed by Dunn's multiple comparisons tests when appropriate. Pairwise comparisons between OVX and OVX $+\mathrm{E}$ treatments within each time group were performed using two-tailed $t$ tests, or Mann-Whitney tests when appropriate. PSCs before and during TTX treatment were compared using two-tailed paired $t$ tests. Data are presented as means \pm SEM. Cumulative probability plots were created by using 100 randomly selected events per cell or all events if $<100$ were recorded. Probability distributions were compared using two-sample Kolmogorov-Smirnov goodness of fit tests (S-PLUS 2000; MathSoft, Cambridge, MA). Statistical significance was set at $p<0.05$.

\section{Results}

\section{GABA transmission to GnRH neurons is directly correlated with estradiol negative and positive feedback}

To examine GABA transmission to $\mathrm{GnRH}$ neurons in relation to the GnRH surge, spontaneous GABAergic postsynaptic currents (sPSCs) were recorded from GFP-identified GnRH neurons in brain slices obtained from OVX $+\mathrm{E}$ or OVX mice. Recordings were performed during times of negative feedback $(-\mathrm{FB})(1100-$ $1400 \mathrm{~h}$ ), surge onset (1400-1600 h), and surge peak (1600-1900 h) in estradiol-treated animals and corresponding times in OVX controls (Fig. 1). Recordings were made from both sagittal and coronal slices, because changes in neurotransmission may depend on the presence of the soma of the afferent cell within the same slice as the recorded cell. It should be noted that normal circuit behavior is inevitably disrupted in an acute slice preparation, independent of slice orientation; nonetheless, the advantage of direct measurement of GABA transmission to $\mathrm{GnRH}$ neurons outweighs this drawback.

There were no diurnal changes in sPSC frequency in cells from OVX mice in either slice orientation (coronal: $-\mathrm{FB}, 0.28 \pm 0.05$ $\mathrm{Hz} ; n=13$ cells; onset, $0.17 \pm 0.06 \mathrm{~Hz} ; n=13$; peak, $0.17 \pm 0.05$ 


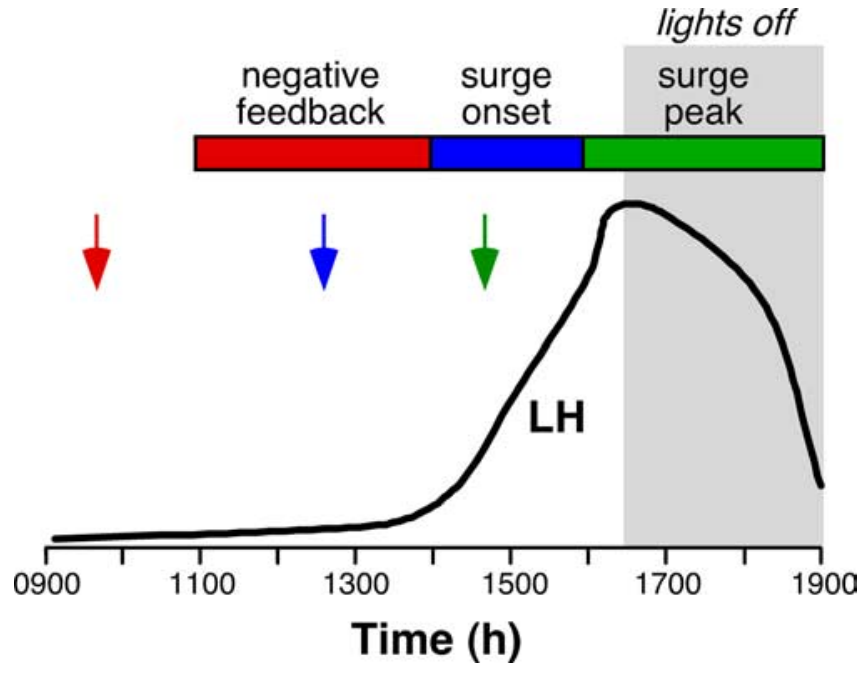

Figure 1. Schematic of experimental design showing times of brain slice preparation (arrows) and recording (bars) relative to $\mathrm{LH}$ surge induction in $\mathrm{OVX}+\mathrm{E}$ mice. No surges occur in OVX mice; for OVX groups, times of slice preparation and recording were matched to times of negative feedback (red), surge onset (blue), and surge peak (green) states in OVX+E mice for comparison. The LH surge profile is adapted from mean values reported by Christian et al. (2005).
A

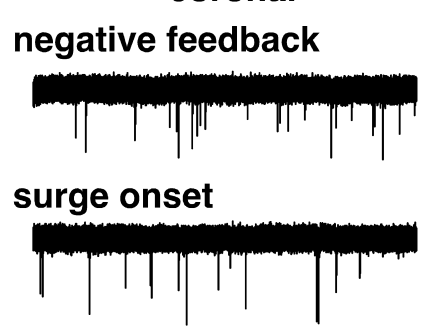

surge peak

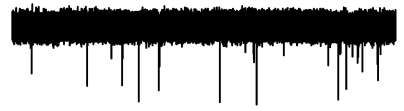

B
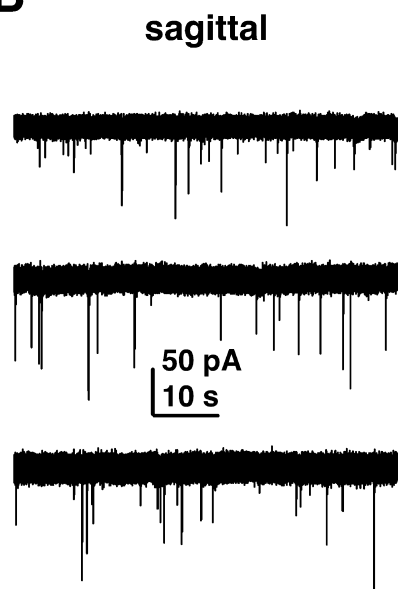

Figure 2. GABA transmission to $\mathrm{GnRH}$ neurons does not change in a diurnal manner in OVX mice. $\boldsymbol{A}, \boldsymbol{B}$, Representative sPSC recordings in coronal $(\boldsymbol{A})$ and sagittal $(\boldsymbol{B})$ slices during negative feedback (top; $n=13$ cells, coronal; $n=12$ sagittal), surge onset (middle; $n=13$ coronal; $n=$ 12 sagittal), and surge peak (bottom; $n=13$ coronal; $n=14$ sagittal).

$\mathrm{Hz} ; n=13$; sagittal: $-\mathrm{FB}, 0.17 \pm 0.04 \mathrm{~Hz} ; n=12$; onset, $0.33 \pm$ $0.07 \mathrm{~Hz} ; n=12$; peak, $0.25 \pm 0.06 \mathrm{~Hz} ; n=14$ ) (Fig. 2), consistent with the lack of change in LH release and GnRH neuron activity in similarly treated mice (Christian et al., 2005). In contrast, in GnRH neurons from OVX +E mice, sPSC frequency was elevated near surge onset in both coronal $(0.55 \pm 0.14 \mathrm{~Hz} ; n=38$; $p<$ $0.01)$ and sagittal slices $(0.54 \pm 0.1 \mathrm{~Hz} ; n=28 ; p<0.01)$ compared with negative feedback (coronal, $0.13 \pm 0.04 \mathrm{~Hz} ; n=18$; sagittal, $0.09 \pm 0.02 \mathrm{~Hz} ; n=15$ ) (Fig. $3 A, B$ ). During the surge peak, this increase subsided in coronal slices $(0.23 \pm 0.04 \mathrm{~Hz} ; n=$ $18 ; p>0.05$ ) (Fig. $3 A, C)$ but persisted in sagittal slices $(0.52 \pm$ $0.1 \mathrm{~Hz} ; n=26 ; p<0.01$ ) (Fig. $3 B, D$ ), suggesting multiple populations of GABA neurons increase transmission in association with surge initiation and maintenance.

Comparison of GABAergic sPSCs in all OVX and OVX $+\mathrm{E}$ cells at each recording time showed estradiol decreased GABA
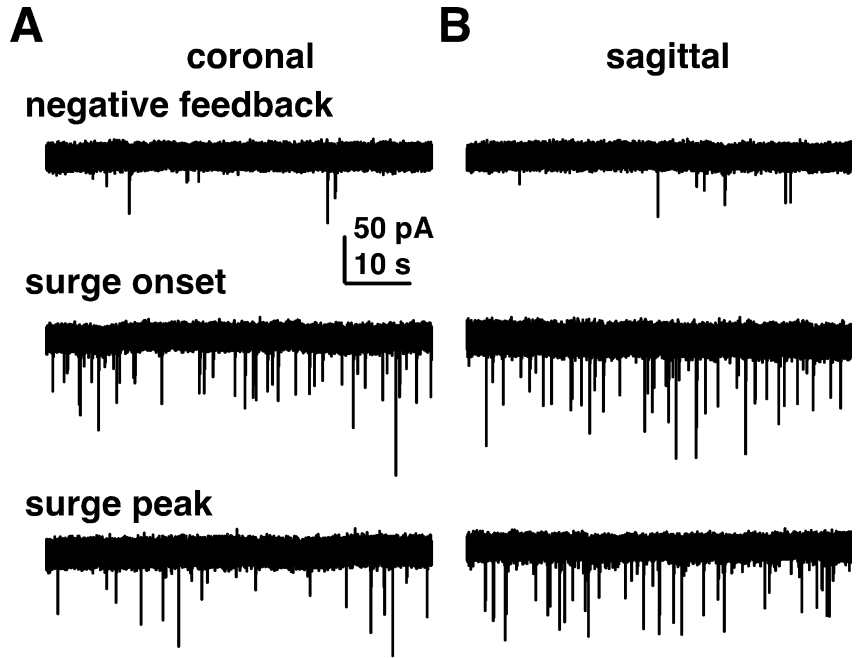

C

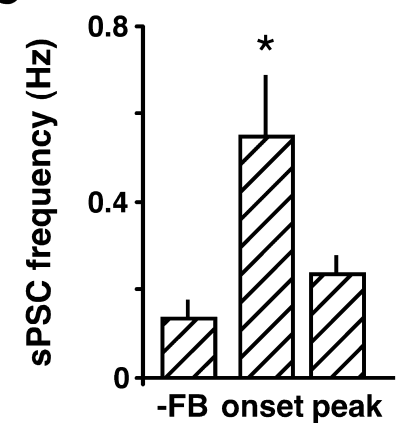

D

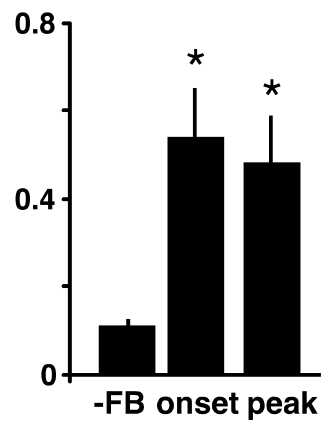

Figure 3. GABA transmission to GnRH neurons increases during the $\mathrm{GnRH} / \mathrm{LH}$ surge in an estradiol-dependent manner. $\boldsymbol{A}, \boldsymbol{B}$, Representative sPSC recordings from cells in coronal $(\boldsymbol{A})$ and sagittal $(\boldsymbol{B})$ slices from OVX +E mice during negative feedback (top; $n=18$ cells coronal; $n=$ 15 sagittal), surge onset (middle; $n=38$ coronal; $n=28$ sagittal), and surge peak (bottom; $n=18$ coronal; $n=26$ sagittal). C, $\boldsymbol{D}$, Mean + SEM sPSC frequency in OVX + E cells in coronal $(\boldsymbol{C})$ and sagittal $(\boldsymbol{D})$ slices. Negative feedback $(-\mathrm{FB})$ values in each slice orientation serve as control. ${ }^{*} p<0.05$.

transmission during negative feedback $(p<0.01)$, but increased transmission during surge onset $(p<0.01)$ and surge peak $(p<$ $0.05)$ (Fig. 4A). Similarly, estradiol increased the interevent interval during negative feedback (Fig. $4 B$ ), but shortened it during surge onset and peak (Fig. $4 C, D$ ). This change in rate of GABA transmission to GnRH neurons induced by estradiol directly correlates with estradiol-induced changes in $\mathrm{GnRH}$ neuron firing activity and LH levels in the same animal model (Christian et al., 2005). Together with the lack of change in LH, firing, or GABA transmission in GnRH neurons from OVX mice, these data suggest one mechanism by which estradiol feedback is conveyed to $\mathrm{GnRH}$ neurons to initiate ovulation is through changes in GABA transmission.

As indicated by the coronal-sagittal differences in sPSC frequency, GnRH neurons receive synaptic information from a variety of anatomically and neurochemically distinct areas (Boehm et al., 2005; Yoon et al., 2005; Wintermantel et al., 2006). The innervation pattern of synaptic inputs to GnRH neurons also varies with reproductive state (Witkin et al., 1991; Jansen et al., 2003; Adams et al., 2006). We examined the relationship between anatomical location of GnRH neurons and degree of GABA transmission associated with the GnRH surge. sPSC frequency was typically $<0.5 \mathrm{~Hz}$ in OVX cells at all times studied, and in $\mathrm{OVX}+\mathrm{E}$ cells during negative feedback. Cells with low sPSC fre- 
quency were distributed throughout the recording area. During the surge, however, a subpopulation of OVX $+\mathrm{E}$ cells (approximately one in three) showed sPSC frequency $>0.5 \mathrm{~Hz}$ (Fig. $5 A, B$ ). These high-frequency values primarily accounted for the changes observed in the overall population. Interestingly, the vast majority of cells exhibiting elevated frequency were located in the midventral preoptic area, and the prevalence of high sPSC frequency was dependent on $\mathrm{GnRH}$ cell body location (coronal, surge onset, rostral to caudal: $n=1$ of 6 cells, $16 \% ; n=$ 10 of 17 cells, $59 \% ; n=4$ of 15 cells, $27 \%$; sagittal, surge onset-peak, medial to lateral: $n=8$ of 14 cells, $57 \% ; n=10$ of 29 cells, 34\%; $n=1$ of 11 cells, 9\%) (Fig. $5 C-F)$. The pattern of cells exhibiting elevated PSC frequency is similar to the pattern of cFos induction in GnRH neurons during the surge (Lee et al., 1990). These data suggest a subpopulation of midline $\mathrm{GnRH}$ neurons receive increased GABA transmission from specific afferent populations to drive the surge.

\section{Estradiol acts on GABA afferents through both activity-dependent and -independent mechanisms}

To begin to distinguish mechanisms that may underlie the observed changes in sPSC frequency, PSCs were recorded before and during in vitro addition of TTX $(0.5 \mu \mathrm{M})$ to block action potential firing, and thus prevent activity-dependent presynaptic GABA release. PSCs recorded in this configuration are attributable to action potential-independent vesicle release, and are referred to as miniature PSCs (mPSCs). TTX did not change PSC frequency in OVX $(n=5 ;-2.5 \pm 1.5 \% ; p>0.05)$ or OVX $+\mathrm{E}(n=5 ; 3.3 \pm$ $3.3 \% ; p>0.05)$ cells recorded during negative feedback. In sagittal slices during surge onset-peak, OVX cells $(n=11)$, and $\mathrm{OVX}+\mathrm{E}$ cells with baseline sPSC frequency $<0.5 \mathrm{~Hz}(n=8)$, showed no decrease in PSC frequency in TTX $(p>0.05)$ (Fig. $6 C-F)$. In contrast, when sPSC frequency in OVX $+\mathrm{E}$ cells was $>0.5 \mathrm{~Hz}$, blocking action potentials markedly decreased transmission in sagittal slices $(n=7$; onset-peak; $p<0.05)$ (Fig. $6 A, E, F)$, but not in coronal slices $(n=5$; onset only; $p>0.05)$ (Fig. $6 B, E, F$ ). If activity-dependent mechanisms were solely accountable for the increase in PSC frequency, then all cells showing elevated frequency would respond to TTX. The lack of a response to TTX in a substantial portion of cells suggests estradiol may act on different GABAergic afferent populations to increase transmission through both activity-dependent and -independent mechanisms.

\section{Investigating sources of surge-associated increases in GABA transmission}

The sources of GABA input that may underlie the observed changes are unknown. Two GABAergic areas that have been implicated in surge regulation are the circadian clock in the suprachiasmatic nucleus (SCN) (Brown-Grant and Raisman, 1977) and the anteroventral periventricular area (AVPV) (Wiegand and Terasawa, 1982). Both of these areas appear to project di-

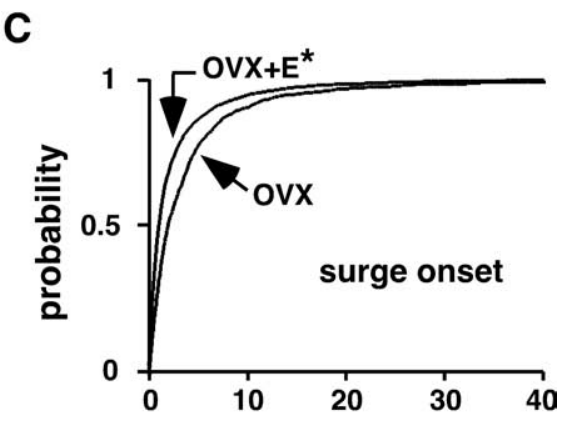

D

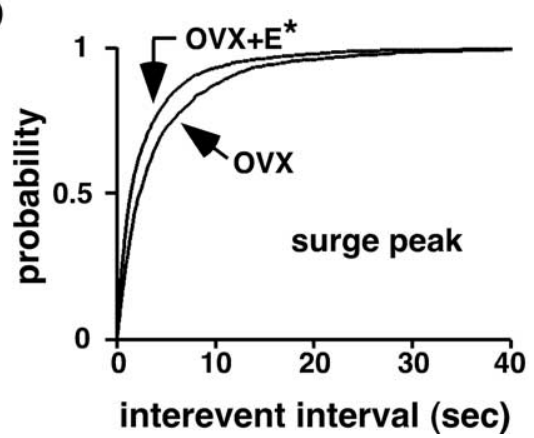

Figure 4. Estradiol decreases $\mathrm{GABA}$ transmission to $\mathrm{GnRH}$ neurons during negative feed back but increases it during surge onset ( during negative feedback but shortens it during surge onset and peak. Cumulative probability distributions for interevent interval during negative feedback (OVX $+\mathrm{E}, n=1232$ events; OVX, $n=1671)(\boldsymbol{B})$, surge onset (OVX $+\mathrm{E}, n=4985 ; 0 \mathrm{VX}, n=1513)(\boldsymbol{C})$, and surge peak (OVX+E, $n=3198 ; 0 \mathrm{VX}, n=1488)(\boldsymbol{D}) .{ }^{*} p<0.05$.

rectly to GnRH neurons (Gu and Simerly, 1997; van der Beek et al., 1997), and the SCN may also project to GnRH neurons indirectly through the AVPV (de la Iglesia et al., 1995; Watson et al., 1995). In the coronal slice orientation, SCN cell bodies are not present in the same slices as GnRH neurons, and only the most caudal slices through the preoptic area would contain AVPV cell bodies. In sagittal slices, both SCN and AVPV cell bodies could be contained within the same slice as $\mathrm{GnRH}$ neurons, although this is more likely in the most medial slices. The locations of these areas thus correspond well with the location of cells exhibiting higher PSC frequency (Fig. 5).

The scattered nature of GnRH neurons has made identification of their afferents difficult, although new genetic approaches hold promise in this regard (Boehm et al., 2005; Yoon et al., 2005; Wintermantel et al., 2006). To begin to examine the roles different sources of GABA afferents may play in surge-associated increases in GABA transmission using a functional approach, we recorded GABAergic PSCs during the surge in sagittal slices in which a razor blade cut (extending $\sim 0.5 \mathrm{~cm}$ dorsal) was placed rostral to the SCN (caudal to the AVPV) to sever SCN-GnRH inputs and other fibers of passage from more caudal inputs ("SCN cut") but preserve inputs from the AVPV (Fig. 7A). In the most medial slice (midsagittal), SCN cut $(n=9$ cells) decreased both mean sPSC frequency $(0.26 \pm 0.05$ cut vs $0.56 \pm 0.1 \mathrm{~Hz}$ intact; $p<0.05)$ and the percentage of cells with sPSC frequency $\geq 0.5 \mathrm{~Hz}$ ( $11 \%$ cut vs $57 \%$ intact) (Fig. $7 \mathrm{~B}, C$ ). In parasagittal slices, SCN cut $(n=17)$ did not change mean sPSC frequency $(0.54 \pm 0.11$ vs $0.6 \pm 0.11 \mathrm{~Hz})$ or percentage of high-frequency cells (35 vs 34\%) (Fig. 7 B, C). In contrast to intact midsagittal and parasagittal slices, in which TTX application decreased PSC frequency (Fig. 6), no high-frequency cells tested in SCN cut slices 
A

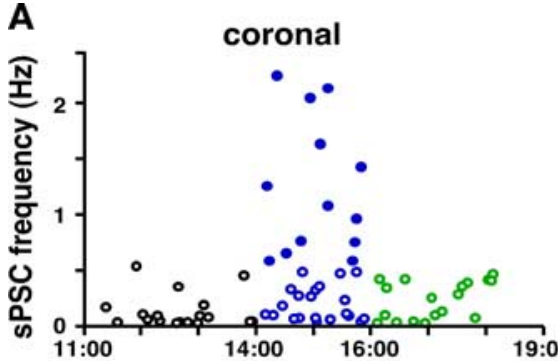

B

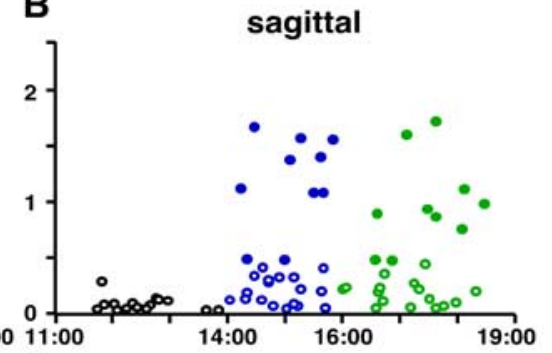

Time (h)

C

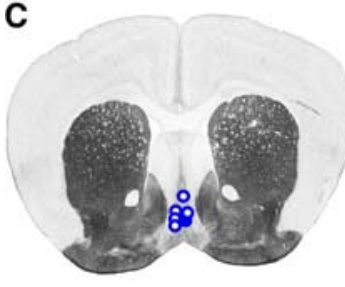

D

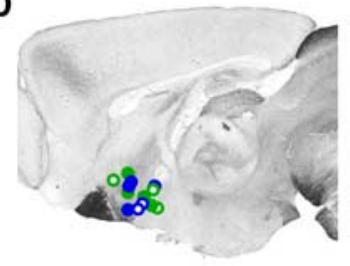

E

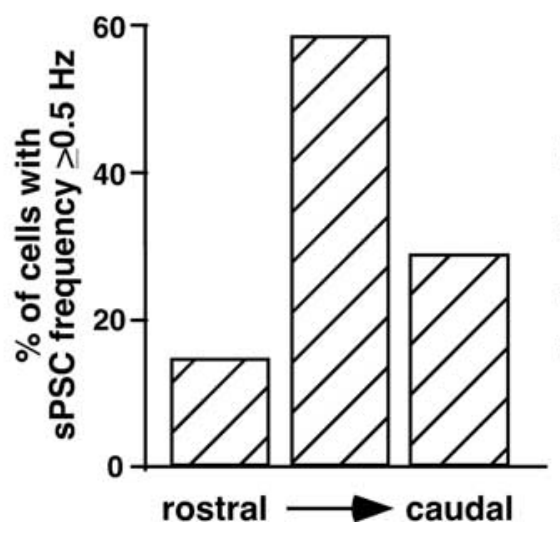

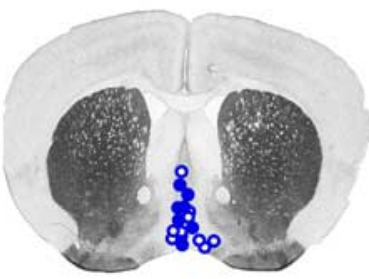

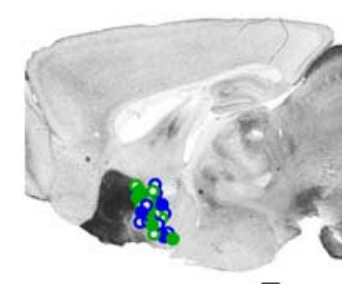

$\mathbf{F}$
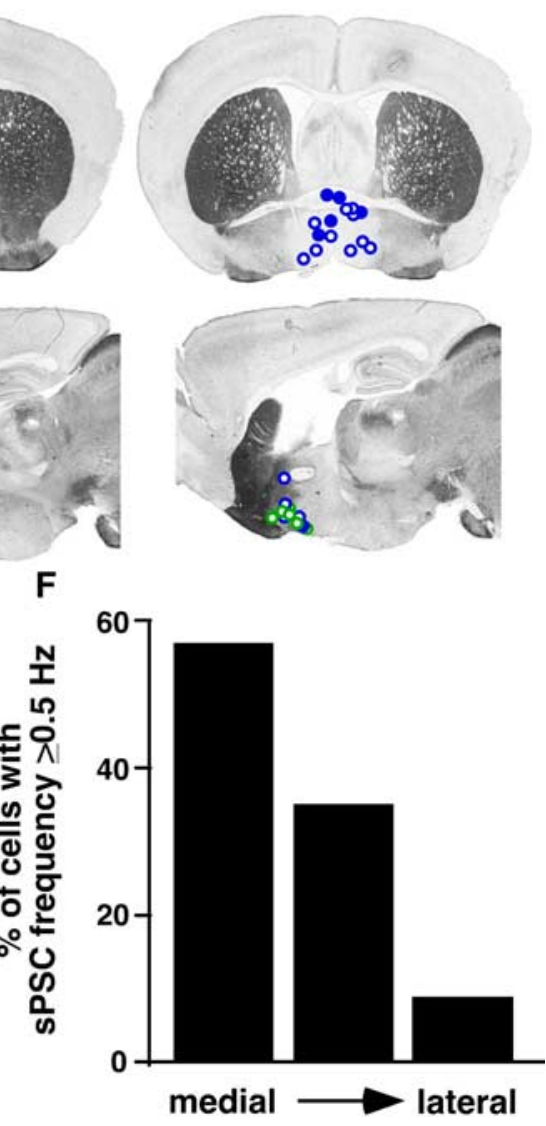

Figure 5. Approximately one in three $\mathrm{GnRH}$ neurons from $\mathrm{OVX}+$ E mice receive estradiol-induced increased GABA transmission during the surge, and this effect correlates with cell location. $A, B, P S C$ frequency in all individual cells from OVX+E mice plotted versus the time of recording in coronal $(\boldsymbol{A})$ and sagittal $(\boldsymbol{B})$ slices. $\boldsymbol{C}, \boldsymbol{D}$, Approximate location of all $G \mathrm{nRH}$ neurons from $0 \mathrm{VX}+\mathrm{E}$ mice recorded during surge onset (coronal and sagittal) and surge peak (sagittal only). Slice images adapted from Paxinos and Franklin (2001). Coronal slices are displayed from rostral (left) to caudal (right), and sagittal slices are displayed medial (left) to lateral (right). The filled circles indicate cells with PSC frequency $>0.5 \mathrm{~Hz}$ during surge onset (coronal and sagittal) and surge peak (sagittal only). The blue circles are cells recorded during surge onset, and the green circles are cells recorded during surge peak. $\boldsymbol{E}$, $\boldsymbol{F}$, Percentage of cells in each slice position that showed PSC frequency $>0.5 \mathrm{~Hz}$ in coronal $(\boldsymbol{E})$ and sagittal $(\boldsymbol{F})$ slices.

responded to TTX ( $n=5$; all parasagittal) (Fig. $7 D)$. Residual high-frequency transmission in SCN cut slices may be derived from the AVPV or other regions undisrupted by the SCN cut. The SCN may therefore be a candidate source of an activitydependent increase in GABA transmission, whereas estradiol may act on the AVPV through activity-independent mechanisms.

PSC amplitude increases during the surge in a diurnal and estradiol-dependent manner

In addition to changes in PSC frequency, we examined diurnal and estradiol-dependent changes in sPSC and mPSC amplitude. As with sPSC frequency, there were no changes in either sPSC or
mPSC amplitude in OVX cells dependent on time of day (Fig. $8 A, B$ ). In OVX $+\mathrm{E}$ cells, in contrast, both sPSC and mPSC amplitude increased during surge onset and peak compared with negative feedback (Fig. $8 A-C)(p<0.01)$. Comparison of mPSC amplitude in OVX and OVX $+\mathrm{E}$ showed no difference during negative feedback, but amplitude was increased in cells from $\mathrm{OVX}+\mathrm{E}$ mice during the surge (Fig. $8 D)(p<0.01)$. Estradiol thus appears to increase PSC amplitude as well as frequency during the surge.

\section{Discussion}

The requirement of the negative-topositive switch in estradiol action for surge generation has long been recognized (Docke and Dorner, 1965), but its underlying mechanisms have remained unknown. Here, we show that, in a manner that directly correlates with changes in GnRH neuron firing activity and downstream pituitary hormone release (Christian et al., 2005), estradiol decreases GABA transmission to GnRH neurons during negative feedback but increases it during the GnRH/LH surge. Estradiol appears to act on multiple populations of GABAergic afferents to exert these effects. These data have implications for understanding the neural regulation of fertility, and further illustrate possible excitatory actions of GABA in the adult brain under normal physiological circumstances.

The changes observed here showing estradiol-induced increases in GABA transmission to GnRH neurons concomitant with the surge contrast with previous whole-animal studies that showed GABA levels in the preoptic area are lower during the LH surge (Jarry et al., 1988; Robinson et al., 1991). These previous data suggested a traditional inhibitory role for GABA in surge regulation. A limitation of that approach is that measures of GABA concentrations do not provide information regarding the types of neurons being affected by any change in GABA. Lower GABA levels may be required to diminish inhibition on upstream excitatory inputs to GnRH neurons, and thereby induce increases in GnRH neuron firing activity characteristic of the surge. Although speculative, an imbalance of hypothalamic GABA levels and disruption of estradiol-induced shifts in GABA transmission may account for the clinical finding of increased incidence of anovulatory cycles in women with epilepsy, and further impairment of ovulation with antiepileptic treatments such as valproate (Morrell et al., 2002).

An increase in synaptic transmission can be attributable to increased activity of presynaptic neurons and/or activityindependent changes such as alterations in vesicle release probability or number of synaptic contacts. Within-cell comparison of PSCs recorded before and during TTX application showed the 
response of OVX $+\mathrm{E}$ cells to TTX depended on baseline PSC frequency, slice orientation, and maintenance of specific afferent connections. TTX decreased GABA transmission in cells with higher baseline frequency in sagittal slices, but not in coronal slices, nor in sagittal slices in which inputs from the SCN were severed. Although the lack of a response to TTX could be attributable solely to loss of points of action potential generation, synaptic strength can be modulated in ways independent of afferent neuronal activity, such as estradiol-induced changes in synapse density observed through the rat estrous cycle (Woolley and McEwen, 1992). Therefore, estradiol may act on multiple afferent cell populations to increase GABA transmission via different mechanisms, increasing firing activity in some populations while altering transmission through activity-independent mechanisms, such as release probability or connectivity, in others.

The amplitude of GABAergic PSCs increased during the surge, suggesting estradiol enhances the efficacy of $\mathrm{GABA}_{\mathrm{A}} \mathrm{R}$ activation in GnRH neurons. Larger PSC amplitude can be attributable to postsynaptic changes such as increased number of receptors and altered receptor composition or phosphorylation, and/or presynaptic changes such as an increase in the amount of GABA released per vesicle. mPSC amplitude, measured in conditions in which presynaptic influences on PSC amplitude are diminished, was larger during the surge. Although this does not exclude increased vesicular concentrations of GABA as a potential source of these changes, it is possible that increased postsynaptic response to GABA at least partially underlies increased PSC amplitude. Therefore, in addition to presynaptic actions to increase PSC frequency, estradiol may also act postsynaptically, perhaps through estradiol receptor- $\beta$ (ER $\beta$ ) (Skynner et al., 1999; Hrabovszky et al., 2001), to increase responsiveness of GnRH neurons to GABA during the surge. LH surges can occur in ER $\beta$ knock-out mice (Krege et al., 1998), however, suggesting that this postsynaptic action of estradiol may be mostly modulatory. Another possibility is that estradiol may act presynaptically through other neurotransmitter or neuromodulator systems to ultimately act on $\mathrm{GnRH}$ neurons and impact $\mathrm{GABA}_{\mathrm{A}} \mathrm{R}$ function. Regardless, increased PSC amplitude leads to larger depolarizations in membrane potential, which, in combination with the effects of estradiol to hyperpolarize action potential threshold (DeFazio and Moenter, 2002) and increase cellular excitability (Chu and Moenter, 2006), would enhance the probability for action potential firing in the postsynaptic GnRH neuron. Thus, similar to changes in PSC frequency, these changes in PSC amplitude are consistent with the increased firing activity and $\mathrm{LH}$ levels observed during positive feedback (Christian et al., 2005).

$\mathrm{GnRH}$ neurons maintain elevated chloride levels in adulthood, leading to a depolarized chloride reversal potential, and fire action potentials in response to local puffs of GABA (DeFazio et al., 2002; Sullivan et al., 2003; Yin et al., 2006). Furthermore, metabotropic glutamate receptor activation reduces both GABA
A
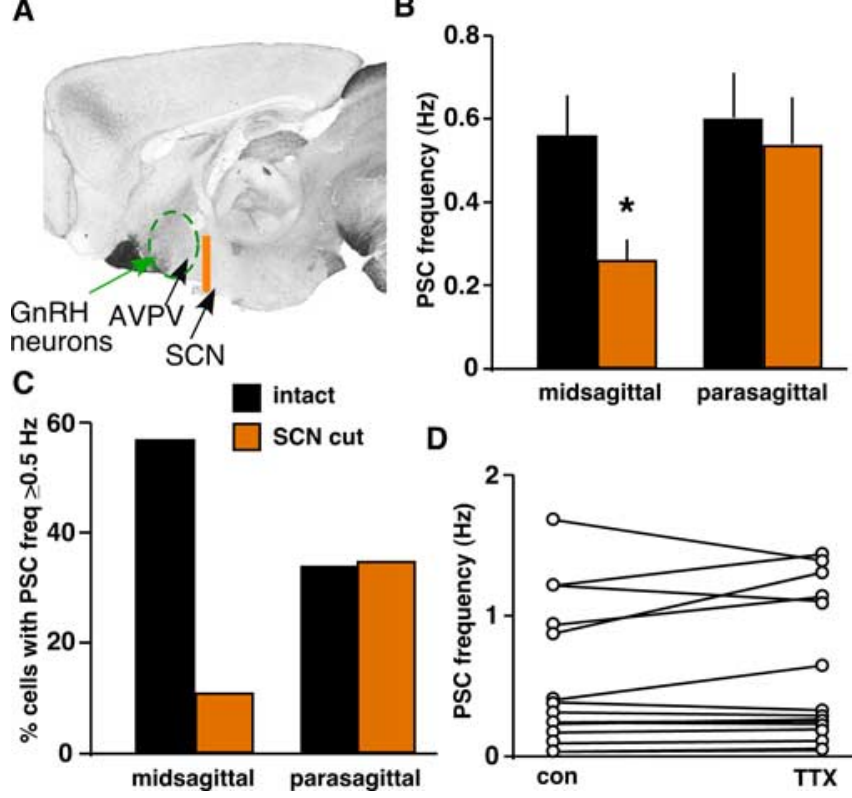

D

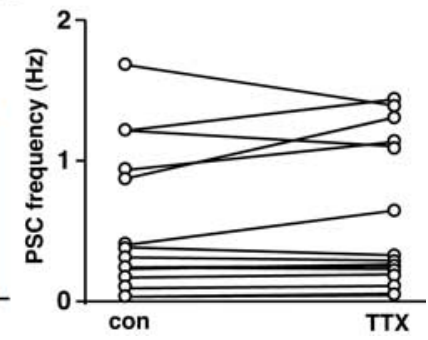

Figure 7. Razor blade cut in between SCN and AVPV alters GABA transmission to GnRH neurons during surge onset-peak. $A$, Location of razor blade cut (orange line) on a midsagittal section in relation to approximate locations of the SCN, AVPV (arrows), and the area containing GnRH neurons (green dashed circle). $\boldsymbol{B}, \boldsymbol{C}$, SCN cut lowers GABAergic sPSC frequency $(\boldsymbol{B})$ and percentage of cells with sPSC frequency $>0.5 \mathrm{~Hz}$ ( $C$ ) in midsagittal slices ( $n=9$ cells) but has no effect in parasagittal slices ( $n=17)$. D, PSC frequency in individual GnRH neurons before (con) and during (TTX) in vitro TTX treatment. No cells exhibiting high control frequency ( $n=5$ of 15) responded to TTX. ${ }^{*} p<0.05$ versus intact slices in respective slice position. 


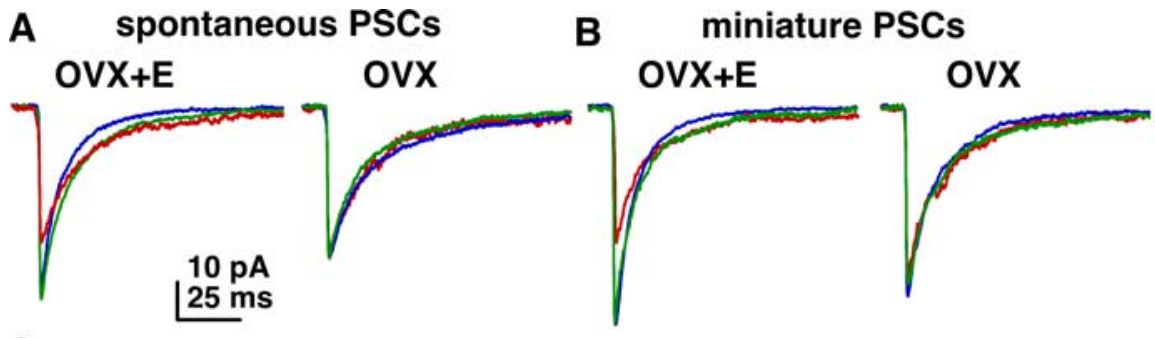

C

D

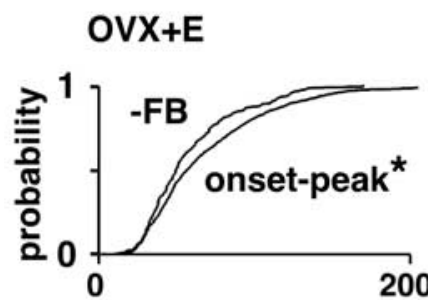

-FB

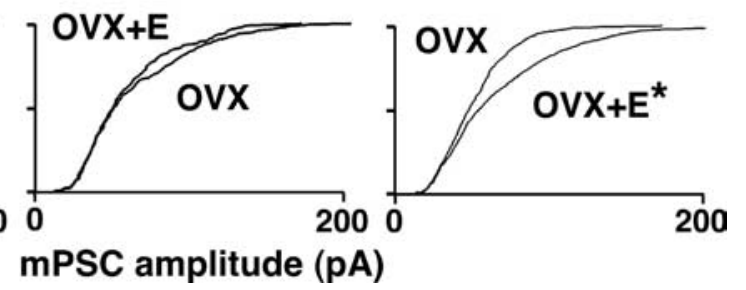

Figure 8. Estradiol modulates amplitude of GABAergic PSCS. $\boldsymbol{A}, \boldsymbol{B}$, Averaged sPSC $(\boldsymbol{A})$ and $\mathrm{mPSC}(\boldsymbol{B})$ traces from representative $\mathrm{OVX}+\mathrm{E}$ (left) and OVX (right) cells during negative feedback (red), surge onset (blue), and surge peak (green). $\boldsymbol{C}$, Cumulative probability distribution for mPSC amplitude comparing events in OVX $+\mathrm{E}$ cells during negative feedback ( $n=205$ events) and combined surge onset and peak times $(n=1104)$. D, Distributions comparing OVX and OVX+E events during negative feedback (top; OVX, $n=333$ ) and combined surge onset and surge peak times (bottom; OVX, $n=758$ ). ${ }^{*} p<0.05$ versus $-\mathrm{FB}(\boldsymbol{C})$ and $\operatorname{OVX}(\boldsymbol{D})$.

sPSC frequency and GnRH neuron firing rate, but antagonism has the reverse effect (Chu and Moenter, 2005). Although a debate remains with regard to the direct effect of GABA on GnRH neurons, the data presented here add to the growing body of functional evidence that when $\mathrm{GnRH}$ neuron activity or LH release is low endogenous GABA transmission to $\mathrm{GnRH}$ neurons is reduced, whereas in states of high-activity GABA transmission is increased (Sullivan et al., 2003; Sullivan and Moenter, 2004a,b, 2005; Pielecka et al., 2006).

The exact sources of GABA input to GnRH neurons that may underlie the changes observed here have yet to be determined. The present studies indicate putative roles for both the SCN and the AVPV as sources of surge-associated increases in GABA transmission. In addition to containing GABAergic cells, both the SCN (Liu and Reppert, 2000) and the AVPV (Herbison and Fenelon, 1995) contain GABA receptors; these areas may be targets for surge-associated decreases in hypothalamic GABA levels. Importantly, AVPV cells express ER $\alpha$ (Simerly et al., 1996), providing a point of integration of estradiol feedback and neural signals. Based on the differences in GABA transmission in SCN cut slices, we propose a working model in which multiple GABAergic populations, including the SCN and AVPV, provide increased GABA transmission to GnRH neurons in association with the surge.

Although the SCN and the AVPV are strong candidates as sources of GABAergic inputs mediating these changes, GnRH neurons receive afferent inputs from other GABAergic populations that may also be involved. The bed nucleus of the stria terminalis (BNST) is another estradiol-sensitive GABAergic area that projects to GnRH neurons (Simerly et al., 1990; Pompolo et al., 2002; Hahn and Coen, 2006). Although electrochemical stimulation in the BNST can cause LH release (Beltramino and Taleisnik, 1980), it provides a much greater input to the medial preoptic area and AVPV in males than in females (Hutton et al., 1998); therefore, it is less likely the BNST plays a significant role in surge regulation. In embryonic nasal explant cultures,
GABAergic cells provide a major synaptic input to GnRH neurons and are involved in GnRH neuron migration (Kusano et al., 1995; Bless et al., 2000); adult roles for these GABA neurons with regard to $\mathrm{GnRH}$ neuron regulation are unknown. Some arcuate nucleus neurons also synthesize GABA (Leranth et al., 1985a) and send projections to the preoptic area ( $\mathrm{Si}$ monian et al., 1999). On proestrus, however, c-Fos expression in the arcuate is very low (Smith et al., 2006), indicating the arcuate may not be involved in surge generation.

Anatomical studies have indicated the number of immunodetectable synaptic contacts on GnRH neurons containing the vesicular GABA transporter (VGAT) decreases at the onset of the LH surge (Ottem et al., 2004). This may indicate fewer contacts; alternatively more frequent GABA release may decrease the pool of vesicles or alter pH (Montana et al., 2004) to change antigen availability of VGAT in an anatomical assay. The present observations clearly indicate a functional increase in GABA transmission to $\mathrm{GnRH}$ neurons; future work will be needed to clarify the source of these afferents.

The present studies indicate estradiol induces shifts in GABA transmission at appropriate times in the diurnal cycle to generate changes in $\mathrm{GnRH}$ neuron firing activity and hormone release characteristic of both negative and positive feedback. It is unlikely that GABA works alone in mediating estradiol feedback, but rather works in concert with other factors, including changes in intrinsic properties, to mediate this switch that is critical for surge regulation, ovulation, and overall female reproductive success. Determining the relative roles of GABA and other factors in surge regulation will be important for understanding the neural control of reproduction in both normal and impaired states.

\section{References}

Adams VL, Goodman RL, Salm AK, Coolen LM, Karsch FJ, Lehman MN (2006) Morphological plasticity in the neural circuitry responsible for seasonal breeding in the ewe. Endocrinology 147:4843-4851.

Barry PH (1994) JPCalc, a software package for calculating liquid junction potential corrections in patch-clamp, intracellular, epithelial and bilayer measurements and for correcting junction potential measurements. J Neurosci Methods 51:107-116.

Beltramino C, Taleisnik S (1980) Dual action of electrochemical stimulation of the bed nucleus of the stria terminalis on the release of LH. Neuroendocrinology 30:238-242.

Bilger M, Heger S, Brann DW, Paredes A, Ojeda SR (2001) A conditional tetracycline-regulated increase in gamma aminobutyric acid production near luteinizing hormone-releasing hormone nerve terminals disrupts estrous cyclicity in the rat. Endocrinology 142:2102-2114.

Bless EP, Westaway WA, Schwarting GA, Tobet SA (2000) Effects of gamma-aminobutyric acid(A) receptor manipulation on migrating gonadotropin-releasing hormone neurons through the entire migratory route in vivo and in vitro. Endocrinology 141:1254-1262.

Boehm U, Zou Z, Buck LB (2005) Feedback loops link odor and pheromone signaling with reproduction. Cell 123:683-695.

Brown-Grant K, Raisman G (1977) Abnormalities in reproductive function associated with the destruction of the suprachiasmatic nuclei in female rats. Proc R Soc Lond B Biol Sci 198:279-296.

Christian CA, Mobley JL, Moenter SM (2005) Diurnal and estradioldependent changes in gonadotropin-releasing hormone neuron firing activity. Proc Natl Acad Sci USA 102:15682-15687. 
Chu Z, Moenter SM (2005) Endogenous activation of metabotropic glutamate receptors modulates GABAergic transmission to gonadotropinreleasing hormone neurons and alters their firing rate: a possible local feedback circuit. J Neurosci 25:5740-5749.

Chu Z, Moenter SM (2006) Physiologic regulation of a tetrodotoxinsensitive sodium influx that mediates a slow afterdepolarization potential in gonadotropin-releasing hormone neurons: possible implications for the central regulation of fertility. J Neurosci 26:11961-11973.

Couse JF, Korach KS (1999) Estrogen receptor null mice: what have we learned and where will they lead us? Endocr Rev 20:358-417.

DeFazio RA, Moenter SM (2002) Estradiol feedback alters potassium currents and firing properties of gonadotropin-releasing hormone neurons. Mol Endocrinol 16:2255-2265.

DeFazio RA, Heger S, Ojeda SR, Moenter SM (2002) Activation of A-type $\gamma$-aminobutyric acid receptors excites gonadotropin-releasing hormone neurons. Mol Endocrinol 16:2872-2891.

de la Iglesia HO, Blaustein JD, Bittman EL (1995) The suprachiasmatic area in the female hamster projects to neurons containing estrogen receptors and GnRH. NeuroReport 6:1715-1722.

Docke F, Dorner G (1965) The mechanism of the induction of ovulation by oestrogens. J Endocrinol 33:491-499.

Flugge G, Oertel WH, Wuttke W (1986) Evidence for estrogen-receptive GABAergic neurons in the preoptic/anterior hypothalamic area of the rat brain. Neuroendocrinology 43:1-5.

Gu GB, Simerly RB (1997) Projections of the sexually dimorphic anteroventral periventricular nucleus in the female rat. J Comp Neurol 384:142-164.

Hahn JD, Coen CW (2006) Comparative study of the sources of neuronal projections to the site of gonadotrophin-releasing hormone perikarya and to the anteroventral periventricular nucleus in female rats. J Comp Neurol 494:190-214.

Han SK, Abraham IM, Herbison AE (2002) Effect of GABA on GnRH neurons switches from depolarization to hyperpolarization at puberty in the female mouse. Endocrinology 143:1459-1466.

Han SK, Todman MG, Herbison AE (2004) Endogenous GABA release inhibits the firing of adult gonadotropin-releasing hormone neurons. Endocrinology 145:495-499.

Herbison AE (1998) Multimodal influence of estrogen upon gonadotropinreleasing hormone neurons. Endocr Rev 19:302-330.

Herbison AE, Fenelon VS (1995) Estrogen regulation of GABAA receptor subunit mRNA expression in preoptic area and bed nucleus of the stria terminalis of female rat brain. J Neurosci 15:2328-2337.

Hrabovszky E, Steinhauser A, Barabas K, Shughrue PJ, Petersen SL, Merchenthaler I, Liposits Z (2001) Estrogen receptor-beta immunoreactivity in luteinizing hormone-releasing hormone neurons of the rat brain. Endocrinology 142:3261-3264.

Hutton LA, Gu G, Simerly RB (1998) Development of a sexually dimorphic projection from the bed nuclei of the stria terminalis to the anteroventral periventricular nucleus in the rat. J Neurosci 18:3003-3013.

Jansen HT, Cutter C, Hardy S, Lehman MN, Goodman RL (2003) Seasonal plasticity within the GnRH system of the ewe: changes in identified GnRH inputs and in glial association. Endocrinology 144:3663-3676.

Jarry H, Perschl A, Wuttke W (1988) Further evidence that preoptic anterior hypothalamic GABAergic neurons are part of the GnRH pulse and surge generator. Acta Endocrinol 118:573-579.

Kaila K (1994) Ionic basis of GABAA receptor channel function in the nervous system. Prog Neurobiol 42:489-537.

Kerdelhue B, Brown S, Lenoir V, Queenan JT, Jones GS, Scholler R, Jones HW (2002) Timing of initiation of the preovulatory luteinizing hormone surge and its relationship with the circadian cortisol rhythm in the human. Neuroendocrinology 75:158-163.

Krege JH, Hodgin JB, Couse JF, Enmark E, Warner M, Mahler JF, Sar M, Korach KS, Gustafsson JA, Smithies O (1998) Generation and reproductive phenotypes of mice lacking estrogen receptor beta. Proc Natl Acad Sci USA 95:15677-15682.

Kusano K, Fueshko S, Gainer H, Wray S (1995) Electrical and synaptic properties of embryonic luteinizing hormone-releasing hormone neurons in explant cultures. Proc Natl Acad Sci USA 92:3918-3922.

Lee WS, Smith MS, Hoffman GE (1990) Luteinizing hormone-releasing hormone neurons express Fos protein during the proestrous surge of luteinizing hormone. Proc Natl Acad Sci USA 87:5163-5167.
Legan SJ, Karsch FJ (1975) A daily signal for the LH surge in the rat. Endocrinology 96:57-62.

Leranth C, Sakamoto H, MacLusky NJ, Shanabrough M, Naftolin F (1985a) Estrogen responsive cells in the arcuate nucleus of the rat contain glutamic acid decarboxylase (GAD): an electron microscopic immunocytochemical study. Brain Res 331:376-381.

Leranth C, MacLusky NJ, Sakamoto H, Shanabrough M, Naftolin F (1985b) Glutamic acid decarboxylase-containing axons synapse on LHRH neurons in the rat medial preoptic area. Neuroendocrinology 40:536-539.

Leranth C, Shanabrough M, Naftolin F (1991) Estrogen induces ultrastructural changes in progesterone receptor-containing GABA neurons of the primate hypothalamus. Neuroendocrinology 54:571-579.

Liu C, Reppert SM (2000) GABA synchronizes clock cells within the suprachiasmatic circadian clock. Neuron 25:123-128.

Marty A, Llano I (2005) Excitatory effects of GABA in established brain networks. Trends Neurosci 28:284-289.

Moenter SM, DeFazio RA (2005) Endogenous gamma-aminobutyric acid can excite gonadotropin-releasing hormone neurons. Endocrinology 146:5374-5379.

Moenter SM, Caraty A, Locatelli A, Karsch FJ (1991) Pattern of gonadotropin-releasing hormone $(\mathrm{GnRH})$ secretion leading up to ovulation in the ewe: existence of a preovulatory $\mathrm{GnRH}$ surge. Endocrinology 129:1175-1182.

Montana V, Ni Y, Sunjara V, Hua X, Parpura V (2004) Vesicular glutamate transporter-dependent glutamate release from astrocytes. J Neurosci 24:2633-2642.

Morrell MJ, Giudice L, Flynn KL, Seale CG, Paulson AJ, Done S, Flaster E, Ferin M, Sauer MV (2002) Predictors of ovulatory failure in women with epilepsy. Ann Neurol 52:704-711.

Norman RL, Blake CA, Sawyer CH (1973) Estrogen-dependent 24-hour periodicity in pituitary LH release in the female hamster. Endocrinology 93:965-970.

Nunemaker CS, DeFazio RA, Moenter SM (2002) Estradiol-sensitive afferents modulate long-term episodic firing patterns of GnRH neurons. Endocrinology 143:2284-2292.

Nunemaker CS, DeFazio RA, Moenter SM (2003) A targeted extracellular approach for recording long-term firing patterns of excitable cells: a practical guide. Biol Proced Online 5:53-62.

Ottem EN, Godwin JG, Krishnan S, Petersen SL (2004) Dual-phenotype GABA/glutamate neurons in adult preoptic area: sexual dimorphism and function. J Neurosci 24:8097-8105.

Pau KY, Berria M, Hess DL, Spies HG (1993) Preovulatory gonadotropinreleasing hormone surge in ovarian-intact rhesus macaques. Endocrinology 133:1650-1656.

Paxinos G, Franklin KBJ (2001) The mouse brain in stereotaxic coordinates, Ed 2. San Diego: Academic.

Pielecka J, Quaynor SD, Moenter SM (2006) Androgens increase gonadotropin-releasing hormone neuron firing activity in females and interfere with progesterone negative feedback. Endocrinology 147:1474-1479.

Pompolo S, Scott CJ, Clarke IJ (2002) Selective regulation of glutamic decarboxylase isoform 65 , but not isoform 67 , in the bed nucleus of the stria terminalis and the preoptic area of the ewe brain across the estrous cycle. Endocrinology 143:544-550.

Pompolo S, Pereira A, Kaneko T, Clarke IJ (2003) Seasonal changes in the inputs to gonadotropin-releasing hormone neurones in the ewe brain: an assessment by conventional fluorescence and confocal microscopy. J Neuroendocrinol 15:538-545.

Rivera C, Voipio J, Payne JA, Ruusuvuori E, Lahtinen H, Lamsa K, Pirvola U, Saarma M, Kaila K (1999) The $\mathrm{K}^{+} / \mathrm{Cl}^{-}$co-transporter KCC2 renders GABA hyperpolarizing during neuronal maturation. Nature 397:251-255.

Robinson J, Kendrick K, Lambart C (1991) Changes in the release of gamma-aminobutyric acid and catecholamines in the preoptic/septal area prior to and during the preovulatory surge of luteinizing hormone in the ewe. J Neuroendocrinol 3:393-399.

Sarkar DK, Chiappa SA, Fink G, Sherwood NM (1976) Gonadotropinreleasing hormone surge in pro-oestrous rats. Nature 264:461-463.

Sim JA, Skynner MJ, Pape JR, Herbison AE (2000) Late postnatal reorganization of GABA(A) receptor signalling in native GnRH neurons. Eur J Neurosci 12:3497-3504.

Simerly RB, Chang C, Muramatsu M, Swanson LW (1990) Distribution of 
androgen and oestrogen receptor mRNA-containing cells in the rat brain: an in situ hybridization study. J Comp Neurol 294:76-95.

Simerly RB, Carr AM, Zee MC, Lorang D (1996) Ovarian steroid regulation of estrogen and progesterone receptor messenger ribonucleic acid in the anteroventral periventricular nucleus of the rat. J Neuroendocrinol 8:45-56.

Simonian SX, Spratt DP, Herbison AE (1999) Identification and characterization of estrogen receptor alpha-containing neurons projecting to the vicinity of the gonadotropin-releasing hormone perikarya in the rostral preoptic area of the rat. J Comp Neurol 411:346-358.

Skynner MJ, Sim JA, Herbison AE (1999) Detection of estrogen receptor alpha and beta messenger ribonucleic acids in adult gonadotropinreleasing hormone neurons. Endocrinology 140:5195-5201.

Smith JT, Popa SM, Clifton DK, Hoffman GE, Steiner RA (2006) Kiss1 neurons in the forebrain as central processors for generating the preovulatory luteinizing hormone surge. J Neurosci 26:6687-6694.

Sullivan SD, Moenter SM (2004a) Gamma-aminobutyric acid neurons integrate and rapidly transmit permissive and inhibitory metabolic cues to gonadotropin-releasing hormone neurons. Endocrinology 145: $1194-1202$.

Sullivan SD, Moenter SM (2004b) Prenatal androgens alter GABAergic drive to gonadotropin-releasing hormone neurons: implications for a common fertility disorder. Proc Natl Acad Sci USA 101:7129-7134.

Sullivan SD, Moenter SM (2005) GABAergic integration of progesterone and androgen feedback to gonadotropin-releasing hormone neurons. Biol Reprod 72:33-41.

Sullivan SD, DeFazio RA, Moenter SM (2003) Metabolic regulation of fertility through presynaptic and postsynaptic signaling to gonadotropinreleasing hormone neurons. J Neurosci 23:8578-8585.

Suter KJ, Song WJ, Sampson TL, Wuarin JP, Saunders JT, Dudek FE, Moenter SM (2000) Genetic targeting of green fluorescent protein to gonadotropin-releasing hormone neurons: characterization of whole-cell electrophysiological properties and morphology. Endocrinology 141:412-419.

van der Beek EM, Horvath TL, Wiegant VM, Van den Hurk R, Buijs RM (1997) Evidence for a direct neuronal pathway from the suprachiasmatic nucleus to the gonadotropin-releasing hormone system: combined tracing and light and electron microscopic immunocytochemical studies. J Comp Neurol 384:569-579.

Watson RE, Langub MC, Engle MG, Maley BE (1995) Estrogen-receptive neurons in the anteroventral periventricular nucleus are synaptic targets of the suprachiasmatic nucleus to the gonadotropin-releasing hormone system: combined tracing and light and electron microscopic immunocytochemical studies. Brain Res 689:254-264.

Wiegand SJ, Terasawa E (1982) Discrete lesions reveal functional heterogeneity of suprachiasmatic structures in regulation of gonadotropin secretion in the female rat. Neuroendocrinology 34:395-404.

Wintermantel TM, Campbell RE, Porteous R, Bock D, Grone H-J, Todman MG, Korach KS, Greiner E, Perez CA, Schutz G, Herbison AE (2006) Definition of estrogen receptor pathway critical for estrogen positive feedback to gonadotropin-releasing hormone neurons and fertility. Neuron 52:271-280.

Witkin JW, Ferin M, Popilskis SJ, Silverman AJ (1991) Effects of gonadal steroids on the ultrastructure of GnRH neurons in the rhesus monkey: synaptic input and glial apposition. Endocrinology 129:1083-1092.

Woolley CS, McEwen BS (1992) Estradiol mediates fluctuation in hippocampal synapse density during the estrous cycle in the adult rat. J Neurosci 12:2549-2554.

Yin C, Tanaka N, Kato M, Sakuma Y (2006) GABA depolarizes GnRH neurons isolated from adult GnRH-EGFP transgenic rats. Neurosci Res 55S:S159.

Yoon H, Enquist LW, Dulac C (2005) Olfactory inputs to hypothalamic neurons controlling reproduction and fertility. Cell 123:669-682. 